\title{
Strategic Measures for Food Processing and Manufacturing Facilities to Combat Coronavirus Pandemic (COVID-19)
}

\author{
Muhammad Shahbaz ${ }^{1 *}$ (D) Muhammad Bilal $^{2}$ (D) Muhammad Akhlaq $^{3}$ (D), \\ Abdul Moiz ${ }^{4}$, Shagufta Zubair ${ }^{5}$ (D) and Hafiz M.N. Iqbal ${ }^{6}$ (D) \\ ${ }^{1}$ Mawarid Food Company, Al Wizarat, Riyadh 12622, Saudi Arabia. ${ }^{2}$ School of Life Science and Food Engineering, \\ Huaiyin Institute of Technology, Huaian 223003, China. ${ }^{3}$ Institute of Agricultural Sciences, University of the Punjab, \\ Lahore 54590, Pakistan. ${ }^{4}$ Section of Chemical and Food Engineering, Department of Industrial Engineering, \\ University of Salerno, Italy. ${ }^{5}$ Dubai Municipality, United Arab Emirates. ${ }^{6}$ Tecnologico de Monterrey, School of \\ Engineering and Sciences, Campus Monterrey, Ave. Eugenio Garza Sada 2501, Monterrey, N.L., CP 64849, Mexico.
}

\begin{abstract}
Coronavirus pandemic (Covid-19) leaves wide-ranging and catastrophic effects at normal ways of living, has disturbed the global food supply chain, and have a damaging impact on food security as well. Food industry and the government should come together to ensure that the food sector should remain open for consistent and unhindered production of food, so consumers have continued access to safe, healthy, and nutritious food during this pandemic. As the countries combat coronavirus pandemic, the food sector must keep gears of food processing and manufacturing moving on to avoid food shortage in the market. To continue the production and supply of safe food at the sites, the food processing and manufacturing facilities have the same level of health challenges which may pose hurdles to consistently of food production. To prevent such issues and critical situation, the food industry needs to take on specific precautions for site and employees to keep them safe and healthy. By appropriately maintaining the food safety systems and with special consideration to combat coronavirus transmission at premises and among employees can help food facilities to not disrupt the flow of manufactured food products and ingredients including food packaging material. Food facilities should strictly monitor staff health, personnel hygiene, and appropriate use of personnel protective equipment at the site entrance and during working and should adopt restrictive visitor policies including suppliers and contractors. Cleaning and disinfection of frequent and high touch points with approved chemicals and sanitizers with defined frequencies and practicing social distances and employee optimization during shifts can be helpful to prevent the spread of coronavirus. The management should limit their visits to the site and monitor the activities by CCTV cameras and food safety audits can be conducted with the use of remote auditing tools. Finally, the facilities should be vigilant to monitor the temperature of staff, employees and visitors, supplier, or contractor to identify if there may any sick person to avoid further spread of coronavirus and shall report to concerned health authorities if anyone symptoms matching with COVID-19.
\end{abstract}

Keywords: Coronavirus, COVID-19, Food safety management, Food processing, Preventive measures

*Correspondence: shahbazfoodtech@gmail.com

(Received: April 22, 2020; accepted: May 04, 2020)

Citation: Shahbaz M, Bilal M, Akhlaq M, Moiz A, Zubair S, Iqbal HMN. Strategic Measures for Food Processing and Manufacturing Facilities to Combat Coronavirus Pandemic (COVID-19). J Pure Appl Microbiol. 2020;14(2):1087-1094. doi: 10.22207/JPAM.14.2.01

(C) The Author(s) 2020. Open Access. This article is distributed under the terms of the Creative Commons Attribution 4.0 International License which permits unrestricted use, sharing, distribution, and reproduction in any medium, provided you give appropriate credit to the original author(s) and the source, provide a link to the Creative Commons license, and indicate if changes were made. 


\section{INTRODUCTION}

The novel coronavirus (COVID-19) is a communicable disease for human beings; reported within December 2019 at the Wuhan, China, and afterward WHO recognized it as a pandemic on 11 March $2020^{1}$. The high transmissibility of Coronavirus makes this pandemic more sensitive toward all kind public engagement ${ }^{2}$. During these extraordinary circumstances, the demand for basic human necessities is increasing dramatically especially for food commodities. The research showed that coronavirus cannot be spread through food or food packaging and yet there is no evidence of that but preventing the spread of COVID-19 among employees is the biggest challenge for the food sector especially food manufacturing and processing organizations. The food manufacturing industry is thriving with its full potential to meet the growing needs, but it is suffering from lack of information, knowledge and regulatory guidelines to perform the operations, properly. The team of food industry experts along with scientists gave an overall food safety mechanism with Precautionary Measures to Limit the Spread of Coronavirus at Food Service and Retail Sector during COVID-193. These guidelines proved effective and being used in KSA and Pakistan. At this time is the biggest support for the food processing and manufacturing industry would be the systemic and interactive food safety management guidelines to enable their full capacity with litter chance of spread of coronavirus among the employees.

Food safety management to combat coronavirus Staff screening and restrictive visitor policies

To keep all the employees safe and to limit the spread of coronavirus during working at the site every employee and visitor including suppliers and contractors should be assessed for COVID-19 symptoms and risk factors each day before entering the facility. The food safety teams or HACCP teams should implement temperature screening and wellness checks of all incoming staff by trained personnel by using calibrated thermometer guns and non-contact or forehead infrared thermometers at the entrance to the facility and any employee who found symptomatic or temperature $100.4^{\circ} \mathrm{F} / 38^{\circ} \mathrm{C}$ or higher, should not allow entering in the facility and should return to home. Temperatures should also check during the start of each shift and then every 4 hours during their job. In most adults, Fever is if the temperature is $100.4^{\circ} \mathrm{F} / 38^{\circ} \mathrm{C}$ or higher. Employees and food handlers who are possibly sick with the symptoms matching COVID-19 should stay home. All those employees with family members or caregivers with symptoms matching COVID-19 should also stay home until full recovery. Staff and managers with coughing, shortness of breath, fever, or other symptoms of illness should not return to work until they are symptom-free.

Any food handler who is running a fever, cough, or exhibits other abnormal symptoms, staff, and managers should help them to contact medical services. Those who refuse to have their temperature check should report to management to stop or remove him/her from work to save other staff members. The team who come to work ill or become ill while at work should send back home immediately to minimize the risk of contamination to food, customers, and other food handlers and staff members. If any food worker has tested positive for COVID-19, the food businesses should report to the health care department and follow their advice. Facilities should designate special entrances that visitors can use to access the food manufacturing facility.

Any visitor found with fever or other symptoms of acute respiratory illness (e.g., cough or shortness of breath) should be instructed to leave the facility and seek care if needed. Facilities should encourage visitors to be aware of signs and symptoms of acute respiratory illness consistent with COVID-19 and not enter the facility if they have such signs and symptoms. Visual alerts, such as signs and posters, should be placed at facility entrances and other strategic areas instructing visitors not to enter as a visitor if they have a fever or respiratory symptoms. Signage should include signs and symptoms of COVID-19 and who to notify if visitors have symptoms. If visitors or contractors are allowed, facilities should follow their protocols regarding the use of masks, gloves, gowns, or shoe covers. Facilities should have staff members who can provide training and education to visitors. All visitors should declare their health status and fill the health declaration form to get authorization from management before entering the facility ${ }^{4}$.

Practice social/physical distances and employee optimization diagonal arrangement

In the food processing and manufacturing 
industry, most of the operations (i.e. raw material screening, transfer of product, quality evaluation, packaging, etc.) are actively utilization of manpower in the processing area mainly in the around assembly line ${ }^{5}$. Underling the guideline of $\mathrm{WHO}^{6,7}$ and keeping in view the most common structure of food processing and manufacturing facilities ${ }^{8}$. The following strategies are recommended to prevent the spread of COVID-19 among employees; Built dividers/barriers between the employees at each workstation as explained in Fig. 1 . In the given pictorial model explains in an interactive way that how should we introduce barriers and dividers among the employees to maintain the appropriate physical distance.

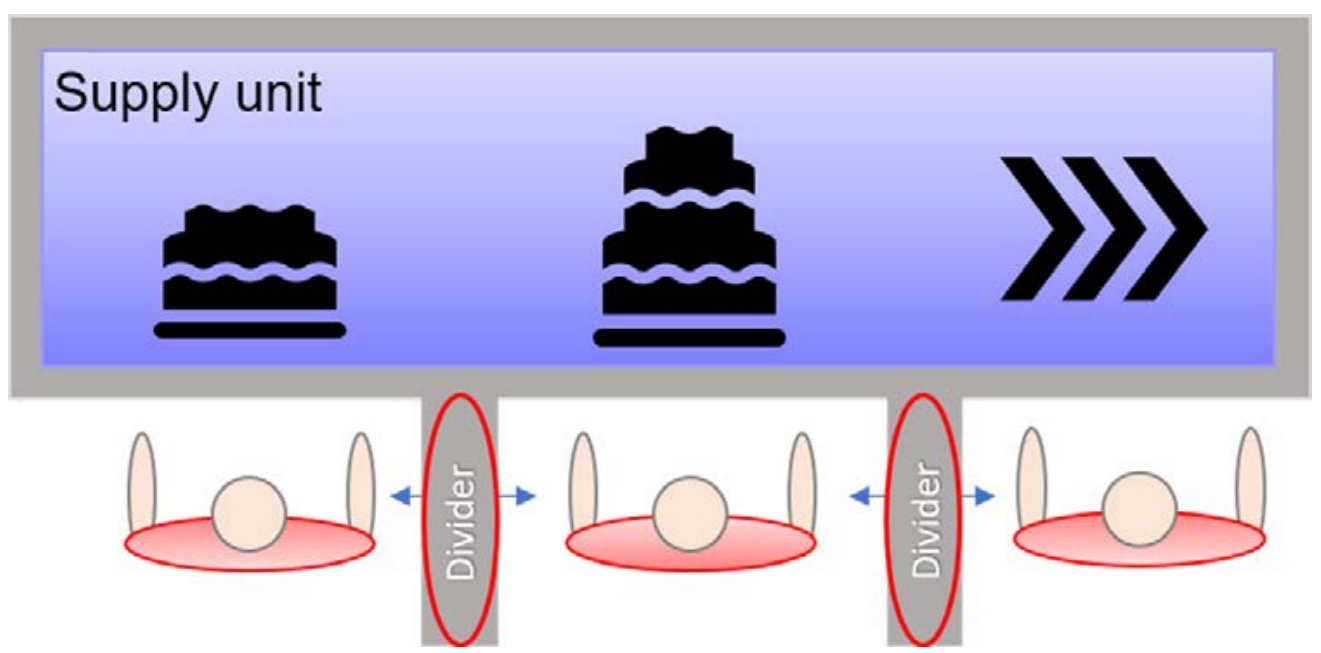

Fig. 1. The top view of a functional assembly line in the food processing industry and installation of dividers/barriers due to Covid-19 for single side engagement of employees.

These dividers should at least cover the upper part of the body of each employee. The divider can be made of any kind of food-grade material with easy maintenance and proper cleaning after each shit. Cases subject to twoway assembly line could be managed by diagonal arrangement and engage employees diagonal setting to each other as shown in Fig. 2.

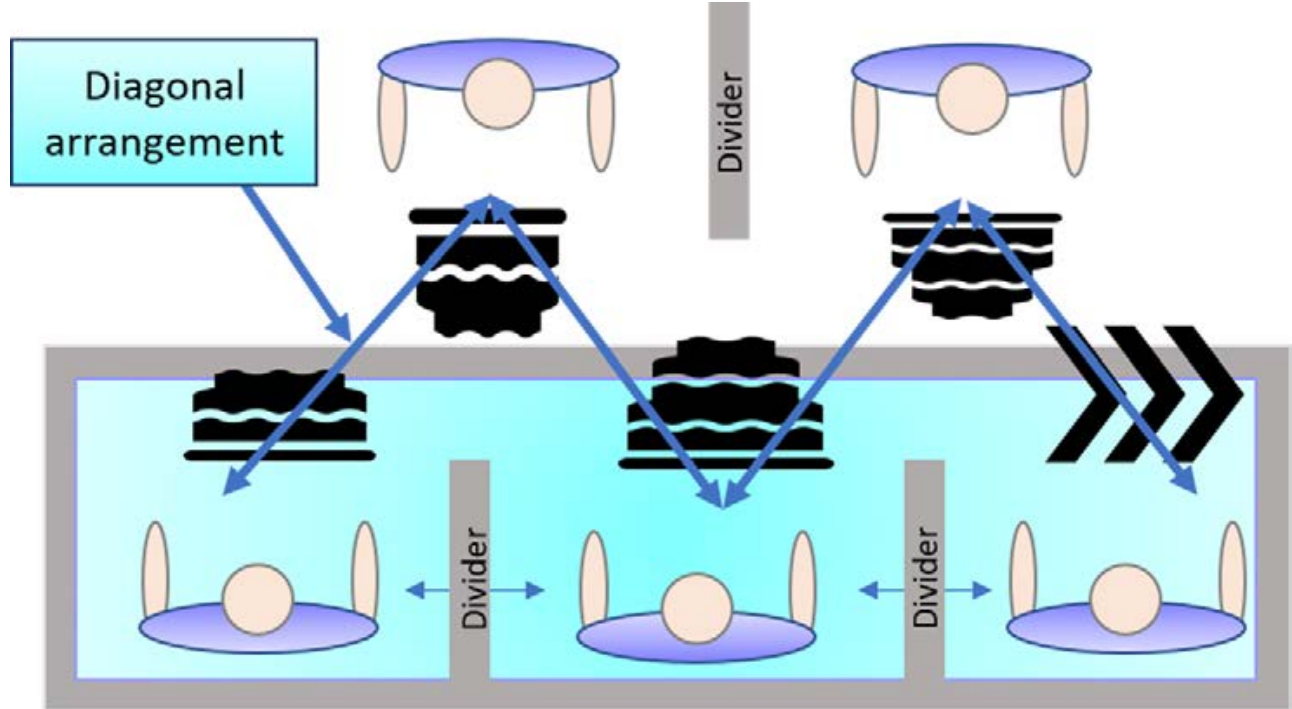

Fig. 2. The top view of a functional assembly line in the food processing industry and installation of dividers/barriers due to Covid-19 for two sides engagement of employees. 
Table 1. List of most common and frequent touchpoints

\begin{tabular}{|c|c|}
\hline $\begin{array}{l}\text { Manufacturing / } \\
\text { Processing } \\
\text { Areas }\end{array}$ & $\begin{array}{l}\text { - Door handles and pushes plates } \\
\text { - Handles of all equipment doors and } \\
\text { - operating pushbuttons } \\
\text { - Elevator buttons } \\
\text { - Escalator handrails } \\
\text { - Refrigerator door handles and } \\
\text { plastic } \\
\text { - Curtains } \\
\text { - Freezers door handles and plastic } \\
\text { - Curtains } \\
\text { - Cleaning Tools } \\
\text { - Trash Receptacles / drums } \\
\text { - Equipment e.g. printers and } \\
\text { - scanners } \\
\text { - Tisplays/screens } \\
\text { - Measuring Instruments e.g., } \\
\text { - thermometers, scales } \\
\text { - Telephone Keypad and Handset } \\
\text { - Computers } \\
\text { - Pens or other writing utensils } \\
\text { - Elevator buttons } \\
\text { - Door handles of material receiving } \\
\text { - vehicles } \\
\text { - Door handles of material } \\
\text { dispatching } \\
\text { - vehicles }\end{array}$ \\
\hline Break $\mathrm{B}$ & $\begin{array}{l}\text { - Door handles and pushes plates } \\
\text { Refrigerator /fridge door } \\
\text { - Tables and Chairs } \\
\text { - Handwash sink handle } \\
\text { - Soap dispenser push plate at } \\
\text { - handwash sink } \\
\text { - Air dryer/towel dispenser handle }\end{array}$ \\
\hline Rest Rooms & $\begin{array}{l}\text { - Door handles } \\
\text { - Sink faucets and toilet handles } \\
\text { - Towel dispenser handle } \\
\text { - Soap dispenser push plates } \\
\text { - Trash receptacle touchpoints }\end{array}$ \\
\hline Off & $\begin{array}{l}\text { - Door handles } \\
\text { - Fingerprints biometric machine } \\
\text { - Telephone Keypad and Handset } \\
\text { - Computers } \\
\text { - Tables and Chairs }\end{array}$ \\
\hline
\end{tabular}

The training of employees is highly important with clear instructions about physical distancing. The employees have a concrete plan with directions on well and floor about leaving their workstation gradually with respect to their adjacent exit. The total number of employees should be divided into equally balanced three to four groups and have different timing of break to avoid overcrowding in the dining area. During the breaks, employees should maintain the distance among each other especially while eating and drinking. Diagonal sitting arrangement is recommended for dining as illustrated in Fig.3.

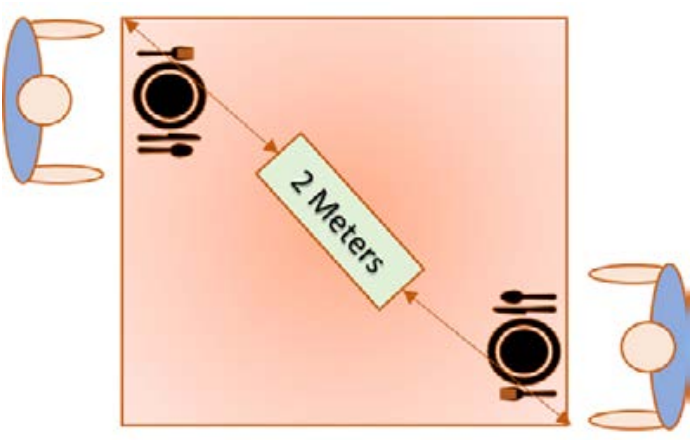

Fig. 3. Siting arrangement in the canteen or dining area without dividers/barriers

\section{Employee optimization}

Covid-19 Pandemic environment accelerates the need for food items, over ripped crops in the field and a limited number of skilled workers generate a high load on food processing and manufacturing industry to feed the world. There are numerous other challenges in the food sector before coronavirus pandemic and now it is multiplied. One of these challenges could resolve to have the optimization of the number of food factory workers to unleash the maximum capacity of food facility and a smaller number of employees as compared to normal refers to a lesser amount of risk in the spread of Covid-19 Among food factory employees and also avoid forcing the worker to perform beyond his or her normal capacity. The approach given by Caparas ${ }^{9}$ is discussed below to calculate the ideal number of food factory workers;

Employee hour per project $=\frac{\text { Total time in completing job }(\text { employee hour }, \text { hr })}{\text { Total output }(\text { products, Unit })}$

Measuring employee-hour per unit of product

Employee hour per project $=$ Total time in completing job (employee hour,hr) / Total output (products,Unit)

Observation sample size

$$
N^{\prime}=\left(\frac{\sqrt[20]{\left(N \sum x^{2}-\left(\sum x\right)^{2}\right)}}{\sum x}\right)
$$


Table 2. Cleaning and disinfection of hard, soft and electronics surfaces

\begin{tabular}{|c|c|c|c|}
\hline Surfaces & Cleaning Method & $\begin{array}{l}\text { Disinfectant for Use } \\
\& \text { Contact Time }\end{array}$ & Disinfection Directions \\
\hline $\begin{array}{l}\text { Hard (Non-Porous) } \\
\text { Tiles, metal, hard } \\
\text { plastics, } \\
\text { water before }\end{array}$ & $\begin{array}{l}\text { Clean the dirty } \\
\text { surfaces with } \\
\text { soap/detergent and } \\
\text { sanitization and } \\
\text { disinfection. }\end{array}$ & $\begin{array}{l}1000 p p m \text { sodium } \\
\text { hypochlorite for at } \\
\text { least } 1 \text { minute }\end{array}$ & $\begin{array}{l}\text { - Diluted household bleach solutions } \\
\text { can be used for these surfaces. } \\
\text { - Follow manufacturer's instructions } \\
\text { for appropriate use and application } \\
\text { - Ensure the product is not expired }\end{array}$ \\
\hline $\begin{array}{l}\text { Soft (porous) } \\
\text { surfaces Linens and } \\
\text { clothing e.g. rugs, } \\
\text { drapes, and carpeted } \\
\text { floor }\end{array}$ & $\begin{array}{l}\text { First remove if there } \\
\text { is any debris or } \\
\text { contamination and } \\
\text { then clean with an } \\
\text { appropriate cleaner. }\end{array}$ & $\begin{array}{l}\text { Warmest Appropriate } \\
\text { Water }\end{array}$ & $\begin{array}{l}\text { - Launder the items as per } \\
\text { manufacturer instructions } \\
\text { - Keep dirty laundry separated from } \\
\text { cleaned laundry. } \\
\text { - Dirty laundry of affected or ill people } \\
\text { should not wash with other people's } \\
\text { items. }\end{array}$ \\
\hline $\begin{array}{l}\text { Electronics Items } \\
\text { e.g. touch screens, } \\
\text { laptops, } \\
\text { computers keyboards, } \\
\text { remote controls, and } \\
\text { vending machines, }\end{array}$ & $\begin{array}{l}\text { First remove if there } \\
\text { is any debris or } \\
\text { contamination and } \\
\text { then clean with an } \\
\text { appropriate cleaner. }\end{array}$ & $\begin{array}{l}\text { Wiping or spraying } \\
\text { with } 70 \% \text { Alcohol }\end{array}$ & $\begin{array}{l}\text { Use of alcohol-based wipes or sprays. } \\
\text { Avoid pooling of liquids at dry surfaces }\end{array}$ \\
\hline
\end{tabular}

Normal time

Normal time $(N T)=\frac{\text { Observed time } x \text { Rating }}{100}$

Standard time

$$
\text { Standard time }=\text { NT } \times(1+\text { Allowance })
$$

Efficiency and Idle \% of the line

$$
E=\frac{\sum \text { Standtime to perform opearation }}{\sum \text { Allowed Standard time }} * 100
$$

Rule of thumb in the optimization of employees is one experienced worker is better than four fresh workers. Use proper operations engineering would lead to minimize wasteful handling and enhance productively. Many softwares are available for these kinds of tasks ${ }^{10,11}$. Cleaning and disinfection of frequent/high touch points

As part of perquisite of food safety management system food facilities already have detailed master cleaning and sanitation programs with defined cleaning and sanitizations tasks and frequency, chemical/sanitizer used, concentration, responsible person and appropriate numbering/ tagging and allocation of cleaning tools being placed in a particular area based on zoning and risk levels. In addition to that and with special focus to prevent the coronavirus spread, the facility should revise and update the cleaning and sanitization programs as per the practical guidance of The U.S. Centers for Disease Control and Prevention (CDC) on cleaning and disinfection to control infectious viruses, such as the novel coronavirus (SARS-CoV-2). As coronavirus is not known to be transmitted through food or food packaging, but coronavirus particles can survive on common, high-touch surfaces, such as stainless steel or door handles. The studies revealed that human CoV can persist on inanimate surfaces such as metal, glass, or plastic for up to 9 days. Surface disinfection with $0.1 \%$ sodium hypochlorite (bleach), $0.5 \%$ hydrogen peroxide, or $62-71 \%$ ethanol could significantly reduce $\mathrm{CoV}$ infectivity on surfaces within $1 \mathrm{~min}$ exposure. A similar effect against the SARS-CoV-2 is expected. A recent study reported that SARSCoV-2 could remain viable in the air for up to 3 hours, on copper for up to 4 hours, on cardboard up to 24 hours, on plastic and stainless steel up to 72 hours. The facility should include the frequent and high touch surfaces in the procedures and monitoring checklists with enhanced frequencies every 15 minutes to 2 hours, or as much as 
necessary to protect the employees by application of EPA (Environment Protection Agency) approved disinfectants ${ }^{12}$. List of most common and frequent touchpoints are summarized in Table 1.

The U.S. Centers for Disease Control and Prevention (CDC) also have special recommendations for cleaning staff to make sure they are appropriately using Personnel protective equipment, wearing disposable gloves, gowns, or work uniforms and washing their hands. The site should provide additional training for the proper use of personal protective equipment ${ }^{13}$. Table 2 summarizes key strategies for cleaning and disinfection of hard, soft and electronics surfaces. Personnel hygiene, hand washing and appropriate use of personal protective equipment

The food handlers and staff workers that handle raw food items such as chicken, milk and fresh vegetables and working in food production or manufacturing areas should use appropriate protective clothing, gloves, masks, hairnets, and should wash their hands frequently, to avoid touching their face, mouth, eyes, and nose to avoid the spread of coronavirus. The employees should not shake hands among each other and with others during working and shift changes. Single-use gloves, disposable aprons, hairnets, shoe covers should be disposed of properly once these become damaged or soiled. Common tools like mops, brooms, rakes, scrapers, or hand tools should be sanitized after each use, especially between two separate users. The handheld temp probes should also sanitize before and end of each task. The facility should provide personal pens and order taking pads separately to order takers, other staff should sanitize their pens at least once per shift. Common use computers, tablets, or touch screens should also be sanitized between users. Hands are also one of the most common ways to spread the virus from one person to the next. Food handlers in manufacturing areas can be directly involved in food production and processing activities which engage them in touching the food contact (utensils, small ware's, trays, tables), nonfood contact surfaces (door handles, walls, handrails, menues, kiosks, chairs, trash bins, dispensers and equipment surfaces (cooler and freezer handles, dressing and preparation table surfaces, computers, tablets, equipment controllers, buttons, touchpads) and cleaning tools, etc. Germs from unwashed hands can be spread and transferred to other surfaces during food production and processing and then transferred to other food handlers and staff as well.

Keeping hands frequently washed and sanitized is the most important and critical steps to evade getting sick and to reduce the spread of the coronavirus at manufacturing facilities. COVID-19 directly spread by not washing hands with soap under clean running water up to the specific time of minimum 20 seconds. CDC recommends cleaning hands as per specific instructions to avoid getting sick and to further spread the germ. The facility management should ensure designated and adequate hands washing facilities are provided and ensure food handlers thoroughly and frequently wash their hands. Handwashing facilities should be equipped with warm running water, normal soap and clean dry paper towels to dry the hands after washing. Hand sanitizers cannot replace handwashing but can be used as an added measure.

\section{Incoming materials/receiving's and deliveries/ dispatches}

The virus can enter in site premises only through infected staff and drivers who entered in premises and handle products or items brought into premises. The site should adopt additional cleaning and sanitation measures while receiving the raw material and dispatching the finished goods.

The staff and drivers who require to receive and dispatch the food products should be provided with alcohol-based hand sanitizer for hand sanitation, to maintain a high degree of personnel hygiene and they need to be aware of practicing physical distancing while picking up deliveries and passing deliveries at the site. Drivers should also ensure that all transport containers are properly cleaned and sanitized before putting food to avoid the spread of coronavirus ${ }^{14}$.

Remote internal and external food safety audits

Food safety audits are extensively used in the food processing and manufacturing sector to evaluate management systems, condition of products and premises, to confirm compliance and to attain certifications against set food safety standards. In coronavirus pandemic where there are travel restrictions and lockdowns, it has 
become a challenge for auditors to travel and to perform onsite audits to ensure compliance to continue the consistency in food safety systems. In such challenging circumstances, the certification bodies have designed to provide the companies with the same level of technical expertise and insights safely and efficiently through remote audits. Also have encouraged internal auditors to perform internal audits as well to meet their external audit requirements.in remote auditing, the auditor reviews the documentation and data through the use of smart cameras and wearable devices. Most of the certification companies have decided to extend the expiration dates of the certificates up to six months to support the clients in these challenging times ${ }^{15}$.

\section{Actions when Employees Tests positive for Covid-19}

Now a day's food production and manufacturing facilities are in the front to meet the people's basic food requirements and these must remain operational to feed the country. Essentially the company should strictly monitor the health of their employees, mostly the companies which have implemented food safety management systems are following employee health policies and illness notification procedures. During coronavirus pandemic, companies should be more vigilant and should screen the temperature of all employees before the start of every shift and then after every 4 hours during working. During working when an employee tests positive for COVID-19 (a confirmed case) or has symptoms (cough, fever, sore throat, shortness of breath) associated with COVID-19 (presumptive or suspected case) then the company should follow the steps suggested by Centre for Disease Control and Prevention (CDC) as follows

Any staff member of an employee who has symptoms associated with COVID-19 (i.e., fever, cough, and/or shortness of breath) or is diagnosed with COVID-19 and at the facility or site, send the employee home immediately. If the employee is at home, do not permit the employee to come to work

Those employees who have not been tested but show symptoms of acute respiratory illness should be excluded from work until they are fully removed and free of fever $\left(100.4^{\circ} \mathrm{F}\left[38.0^{\circ} \mathrm{C}\right.\right.$.
Employees should notify their supervisor and the company should encourage the employee to contact their local health department and seek medical attention upon the initial appearance of symptoms.

Any employees with a tested positive test who have stayed home (home isolated) may be able to return to work if he has no fever for at least 72 hours since recovery (that is three full days and other symptoms have improved (for example, when cough or shortness of breath has improved) and at least 7 days have passed since symptoms first appeared.

Identify individuals who were in close contact within 2 meters ( 6 feet) of a COVID-19 case for a prolonged period; with the infected individual need. Unless advised by local authorities, other individuals in the facility should not be considered high risk for infection, do not require special treatment, and may continue working as normal after surfaces are cleaned and disinfected properly ${ }^{16}$.

\section{ACKNOWLEDGMENTS}

All listed author(s) are thankful to their representative universities/institutes for providing the related support to compile this work.

\section{CONFLICT OF INTEREST}

The authors declare that there is no conflict of interest.

\section{FUNDING}

None.

\section{AUTHORS' CONTRIBUTION}

All listed author(s) have made a substantial, direct, and intellectual contribution to the work, and approved it for publication.

\section{ETHICS STATEMENT}

This article does not contain any studies with human participants or animals performed by any of the authors.

\section{DATA AVAILABILITY}

Not applicable. 


\section{REFERENCES}

1. WHO Director-General's opening remarks at the media briefing on COVID-19 - 11 March 2020. Available online at: https://www.who.int/dg/speeches/detail/whodirector-general-s-opening-remarks-at-the-mediabriefing-on-covid-19-11-march-2020. [Last accessed: April 29, 2020].

2. Bilal M, Nazir MS, Parra-Saldivar R, Iqbal HMN. 2019-nCoV/COVID-19 - Approaches to Viral Vaccine Development and Preventive Measures. J Pure Appl Microbiol. 2020;14:25-29. https://doi.org/10.22207/ JPAM.14.1.05

3. Shahbaz M, Bilal M, Moiz A, Zubair S, Iqbal HMN. Food Safety and COVID-19 : Precautionary Measures to Limit the Spread of Coronavirus at Food Service and Retail Sector. J Pure Appl Microbioly. 2020;14. https://doi. org/10.22207/JPAM.14.SPL1.12

4. Management of Visitors to Healthcare Facilities in the Context of COVID-19: Non-US Healthcare Settings. Available online at: https://www.cdc.gov/ coronavirus/2019-ncov/hcp/non-us-settings/hcfvisitors.html [Last accessed: April 29, 2020].

5. Moerman F, Wouters PC. Hygiene Concepts for Food Factory Design. In Innovation and Future Trends in Food Manufacturing and Supply Chain Technologies. 2016;81-133. Woodhead Publishing. https://doi. org/10.1016/B978-1-78242-447-5.00004-6

6. World Health Organization. Modes of transmission of virus causing COVID-19: implications for IPC precaution recommendations: scientific brief, 27 March 2020. World Health Organization; 2020. Available online at: https://apps.who.int/iris/ bitstream/handle/10665/331601/WHO-2019-nCoVSci_Brief-Transmission_modes-2020.1-eng.pdf [Last accessed: April 29, 2020].

7. World Health Organization. COVID-19 and food fafety: guidance for food businesses: interim guidance, 07 April 2020. World Health Organization; 2020 Apr 7. Available online at: https://apps.who.int/iris/ bitstream/handle/10665/331705/WHO-2019-nCoVFood_Safety-2020.1-eng.pdf [Last accessed: April 29, 2020].

8. Ranken MD, Kill RC, Baker C. Food factory design and operation. InFood Industries Manual 1997;557-573. Springer, Boston, MA. https://doi.org/10.1007/978-
1-4613-1129-4_17

9. Caparas HA. A Decision Support System to Determine the Ideal Number of Workers Using a Line Balancing Method. Journal of Industrial Engineering and Management Science. 2019;2019(1):103-22. https:// doi.org/10.13052/jiems2446-1822.2017.005

10. Top 9 Workforce Optimization Software in 2020 Reviews, Features, Pricing, Comparison - PAT RESEARCH: B2B Reviews, Buying Guides \& Best Practices. Available online at: https://www.predictiveanalyticstoday.com/ top-workforce-optimization-software/\#topworkforce optimizationsoftware [Last accessed: April 29, 2020].

11. 7 Essential Labor Optimization Strategies. Available online at: https://aaronallen.com/blog/restaurantlabor-optimization-strategies [Last accessed: April 29, 2020].

12. Marnie C, Peters MD. ANMF Evidence Brief Covid-19: Cleaning and disinfection of hospital surfaces and equipment. Australian Nursing and Midwifery Federation. 2020. Available online at: http://www. anmf.org.au/documents/ANMF_Evidence_Brief_ COVID-19-Cleaning_and_disinfection.pdf [Last accessed: April 29, 2020].

13. Cleaning and Disinfection for Community Facilities. 2020. Available online at: https://www.cdc.gov/ coronavirus/2019-ncov/community/organizations/ cleaning-disinfection.html [Last accessed: April 29, 2020].

14. World Health Organization. COVID-19 and food fafety: guidance for food businesses: interim guidance, 07 April 2020. World Health Organization; 2020 Apr 7. Available online at: https://apps.who.int/iris/ bitstream/handle/10665/331705/WHO-2019-nCoVFood_Safety-2020.1-eng.pdf [Last accessed: April 29, 2020].

15. Kotsanopoulos KV, Arvanitoyannis IS. The role of auditing, food safety, and food quality standards in the food industry: A review. Comprehensive Reviews in Food Science and Food Safety, 2017; 16(5): 760-75. https://doi.org/10.1111/1541-4337.12293

16. Food Industry Recommended Protocols When Employee/Customer Tests Positive for COVID-19. 2020. Available online at: https://www.nmpf.org/ wp-content/uploads/2020/03/3-23-20-Positive-TestProtocol-Final.pdf [Last accessed: April 29, 2020]. 